\title{
不斉反応の新手法開発とその応用
}

\author{
野出學
}

\section{Development of New Methods in Asymmetric Reactions and Their Applications}

\author{
Manabu NODE \\ Kyoto Pharmaceutical University, 1 Shichono-cho, Misasagi, Yamashina, Kyoto 607-8412, Japan
}

(Received September 10, 2001)

\begin{abstract}
Several novel methods using chiral reagents and biocatalysts for asymmetric reactions are described. Among those reactions, asymmetric reduction via a novel tandem Michael addition/Meerwein-Ponndorf-Verley reduction of acyclic $\alpha, \beta$-unsaturated ketones using a chiral mercapto alcohol, asymmetric synthesis of allene-1,3-dicarboxylate via crystallization induced asymmetric transformation, and improved asymmetric nitroolefination of lactones and lactames at $\alpha-$ carbon using new chiral reagents were developed. In the reactions using biocatalysts, asymmetric dealkoxycarbonylation of bicyclic $\beta$-keto diesters having $\sigma$-symmetry with lipase or esterase to give optically active $\beta$-keto esters, the asymmetric reduction of bicyclic 1,3-diketones having $\sigma$-symmetry with Baker's yeast to give optically active keto alcohols, and the asymmetric aldol reaction of glycine with threonine aldolase were also developed. The above mentioned products were effectively utilized as chiral building blocks for the asymmetric synthesis of natural products and drugs.
\end{abstract}

Key words_— asymmetric reaction; reduction; crystallization; nitroolefination; dealkoxycarbonylation; aldol reaction

\section{1. はじめに}

医薬品には光学活性な化合物が数多く開発されて きている，このため，不斉合成の重要性は年々高ま ってきており, 創薬研究において光学活性体の合成 に役立つと思われる不斉反応の開発を目指すことに した．我々の研究室では大別して次の 2 方法を用い て検討した。すすおち，不斉補助基が導入された反 応剂を用いる不斉反応の開発，及び，酵素などの生 体触媒を用いる不斉反応の開発において，それぞれ 新規な手法を検討することにした。また，開発され た新手法を利用して実際に医薬品や生物活性物質の 不斉合成への応用研究を行った，以下にそれらの研 究成果について概略する。

\section{2. 不斉反応剂を用いる新手法の開発}

2-1. $\alpha, \beta$-不飽和ケトンの各種不斉還元反応 ケトンの Meerwein-Ponndorf-Verley（MPV）還元 反応は古典的反応の 1 つである。この不斉反応に関 する従来の研究では, 分子間 MPV 反応の不斉収率 は $50 \%$ 以下であるのに対し，分子内反応ではほと

京都薬科大学(干607-8412 京都市山科区御陵四丁野町 1) e-mail: node@mb.kyoto-phu.ac.jp

*本総説は, 平成 12 年度宮田専治学術賞の受賞を記念 して記述したものである.
んど 100\%に近い不斉収率で進行している。この不 斉収率の大きな違いは，Chart 1 に示すそれらの遷 移状態の構造的相違（単環性と 2 環性遷移状態）に 基づいていると考えられ，高い不斉収率で進行する 分子内反応に着目した.

従来の分子内反応では基質の合成に大きな制限が あるため, 反応基質と反応剂を連結する新規手法を 考えた．そこで考案された反応は，メルカプト基を もつキラルアルコール 1 (不斉反応剂) とルイス酸 を用いる $\alpha, \beta$-不飽和ケトン 2 の不斉還元反応であ る (Chart 2) . 1,4) 本反応は, Michael 付加反応と MPV 還元反応が連結した反応で，前例のない手法 の開発に成功した，本反応の生成物 $\mathbf{3}$ には硫黄原子 が導入されているため, 脱硫法の選択により多種類 の光学活性アルコールに変換が可能である点に大き な特色がある。

本反応では，従来低い不斉収率であった分子間 MPV 反応を $98 \%$ までに向上させることができた. すなわち，付加体 $\mathbf{A}$ における MPV 反応は，分子 内反応特有の 2 環性の固定化された遷移状態を経る ため，高不斉収率で進行するようになると考えられ る. しかし，MPV 反応は平衡反応であるため, 分 子内反応の化学收率を上げるには $\mathbf{A}, \mathbf{B}$ 間での平衡 


\section{Intermolecular Asymmetric MPV Reaction}

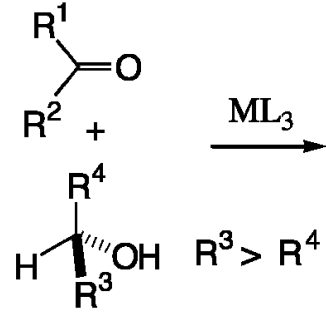

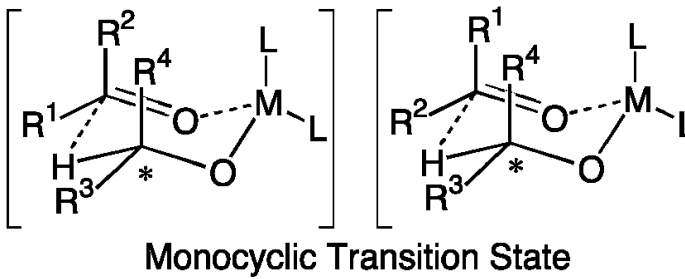<smiles>[R]C([2H])(O)[13CH]C</smiles>

Intramolecular MPV Reaction (1,5 - Hydride Shift)<smiles>[R]C1(CCC(C)=O)C(=O)CC[C@@H]1O</smiles>

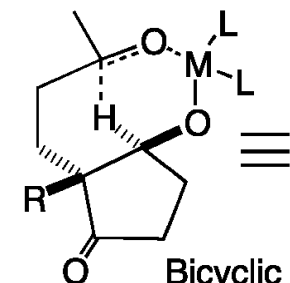

Bicvclic
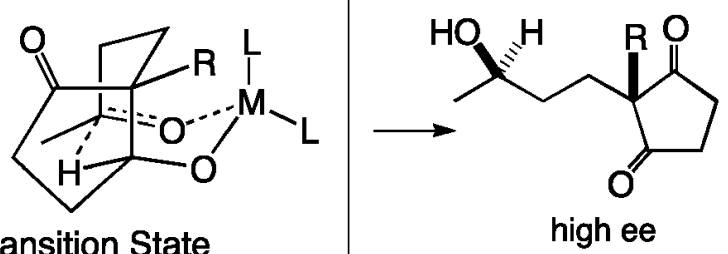

high ee

Chart 1

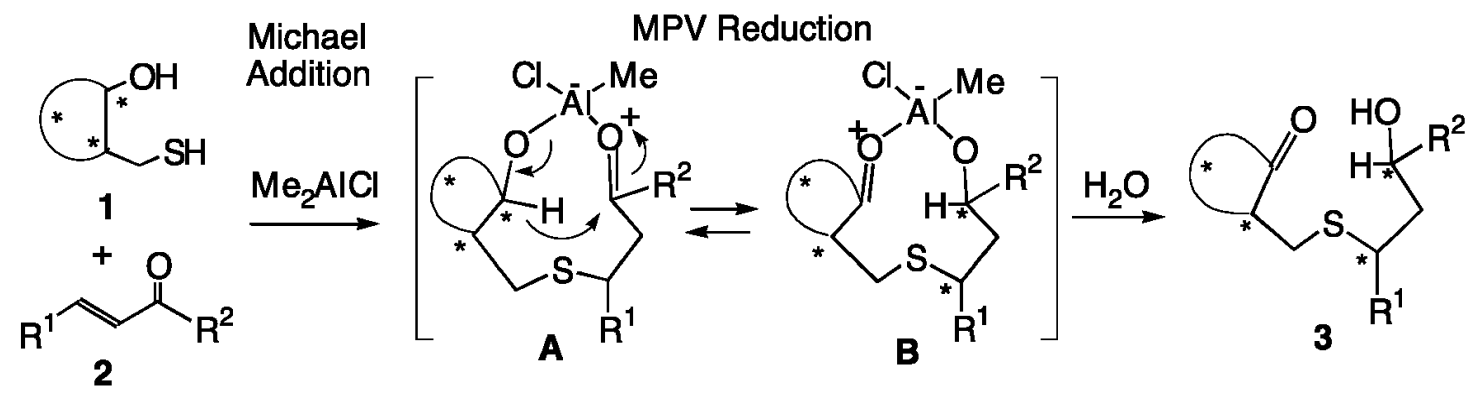

Chart 2

を B 側に偏らせることが問題となる，例えば，プ レゴンから誘導した反応剤を用いた反応では, Michael 付加体と目的の MPV 還元体が略等量得ら れた (Chart 3)。この問題解決に反応剤 1 のアル コール部に 5 員環を採用し，そのアルコール体から ケト体へのエネルギー変化（eclipse の解消に基づ く）を利用して生成物 $\mathbf{3}$ を得ることを計画した.

市販のカンファースルホン酸を還元して得られる 5 員環アルコール 1a を不斉反応剂として用いた場 合（Chart 4）は, Michael 付加体 3a は少量得られ るのみで MPV 還元体が高収率で得られた。本反応 におけるルイス酸としては酸性度の高いもの（例え ば $\mathrm{AlCl}_{3}$ ）を使用すると反応剂の分解が観察され た。本反応剂には, 酸性度の比較的低い $\mathrm{Et}_{2} \mathrm{AlCl}$ が
最も適当であり，反応温度は室温が最適であった．

本反応で得られる生成物 3a は単一化合物であ り, 新規に生成する 2 個の不斉炭素は完全に立体制 御されていた。このスルフィド炭素の不斉誘起は反 応機構の詳細な研究より Michael 付加段階の平衡に 基づく新規な動的速度論分割に基づいていることが 明らかにされた（Chart 5)。

上記生成物の脱硫に関する研究では, 3a の置換 基 $\mathrm{R}^{2}$ が芳香族置換基である場合，通常のラネー $\mathrm{Ni}$ による反応は水酸基部で部分的にラセミ化を起すこ とが観察された。このため, ラセミ化を伴わない還 元的脱硫反応 (ラネー $\mathrm{Ni}$-次亜リン酸組み合せ反応 剂）を新規に開発し，高光学純度の二級アルコール 4 を高収率で得ることに成功した（Table 1)。2,3) 


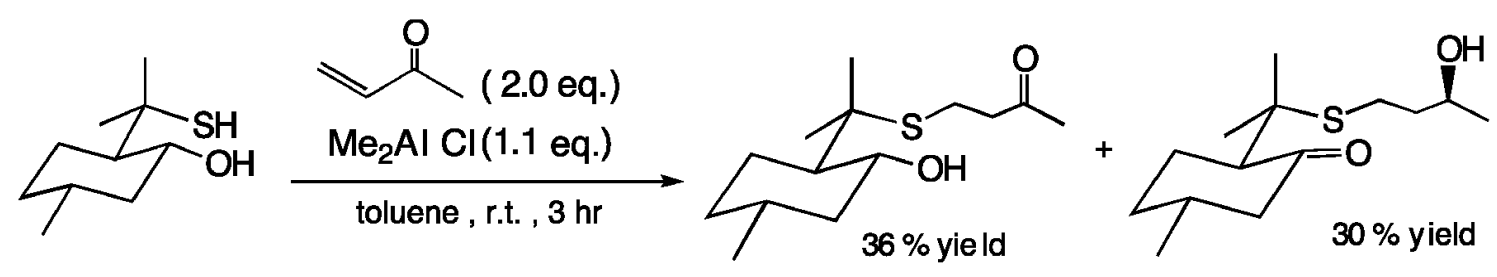

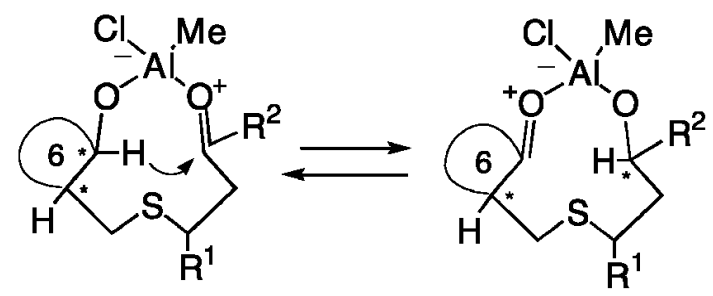

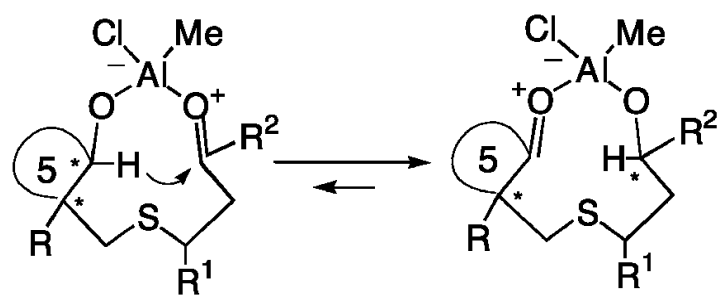

Chart 3<smiles>[R7]C=CC([R])=O</smiles>

2

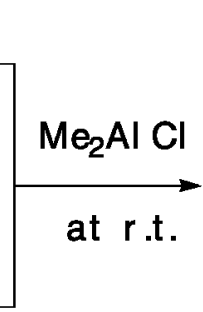

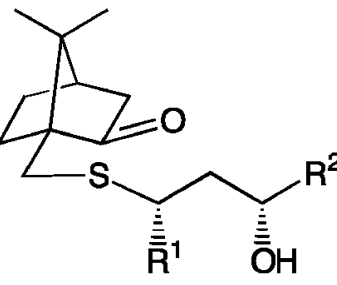

$3 \mathbf{a}$
Reductive Desulfurization

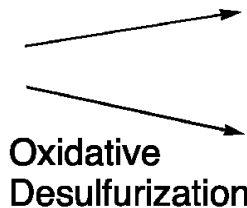

Desulfurization<smiles>[R]CC[C@H]([R])O</smiles><smiles>[R]C=C[C@H]([R])O</smiles>

5

Chart 4

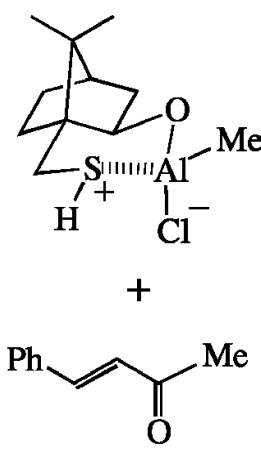
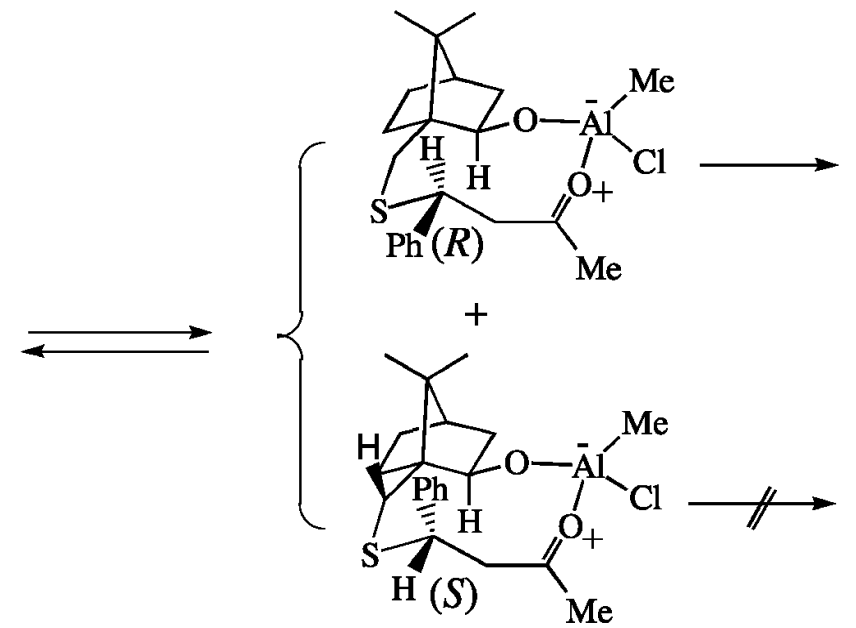

Chart 5. Dynamic Kinetic Resolution via Reversible Michael Addition

上記の脱硫反応はベンジル位に硫黄原子をもつス ルフィドに限られるため，置換基が脂肪族である化 合物には水酸基をベンゾイル基で保護した後，通常
のラネーNiによる脱硫法を用いた（Table 2).

また，スルフィド $\mathbf{3 a}$ の酸化的脱硫反応（スルホ キシドの $\beta$-脱離) では光学活性アリルアルコール 
Table 1. Asymmetric Reduction of $\alpha, \beta$-Unsaturated Ketones

\begin{tabular}{|c|c|c|c|c|c|c|c|c|}
\hline \multicolumn{2}{|c|}{$\left(\mathrm{R}^{1}=\right.$ Aromatic $)$} & \multicolumn{2}{|c|}{$\begin{array}{l}(-)-1 \mathrm{a}(1.2 \mathrm{eq} .) \\
(98 \% \mathrm{ee}) \\
\begin{array}{c}\mathrm{Me} \mathrm{e}_{2} \mathrm{AICl}(1.2 \mathrm{eq} .) \\
\text { r.t. }\end{array}\end{array}$} & \multicolumn{3}{|c|}{ 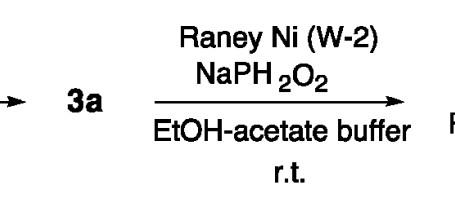 } & \multicolumn{2}{|c|}{$4 a$} \\
\hline \multirow{3}{*}{ entry } & \multicolumn{4}{|c|}{ Tandem Michael-MPV reaction } & \multicolumn{4}{|c|}{ Reductive desulfuration } \\
\hline & \multicolumn{2}{|c|}{ substrate } & \multirow{2}{*}{$\begin{array}{l}\text { time } \\
\text { (h) }\end{array}$} & \multirow{2}{*}{$\begin{array}{c}\text { yield of 3a } \\
(\%)\end{array}$} & \multirow{2}{*}{$\begin{array}{l}\text { time } \\
\text { (h) }\end{array}$} & \multirow{2}{*}{$\begin{array}{c}\text { yield of } 4 a \\
(\%)\end{array}$} & \multirow[t]{2}{*}{$\%$ ee } & \multirow{2}{*}{ Config. } \\
\hline & $\mathrm{R}^{1}$ & $\mathrm{R}^{2}$ & & & & & & \\
\hline 1 & $\mathrm{Ph}$ & $\mathrm{Me}$ & 12 & 83 & 0.6 & 89 & 97 & $s$ \\
\hline 2 & $\mathrm{Ph}$ & Et & 13 & 90 & 0.3 & 91 & 98 & $s$ \\
\hline 3 & $\mathrm{Ph}$ & $\mathrm{n}-\mathrm{Pr}$ & 16 & 81 & 0.3 & 95 & 98 & $s$ \\
\hline 4 & $\mathrm{Ph}$ & $\mathrm{n}-\mathrm{Bu}$ & 12 & 83 & 0.3 & 89 & 97 & $S$ \\
\hline 5 & $\mathrm{Ph}$ & $n-O c$ & 12 & 90 & 0.6 & 99 & 98 & $s$ \\
\hline 6 & $\mathrm{Ph}$ & $\mathrm{Ph}$ & 24 & 85 & 0.3 & 96 & 96 & $R$ \\
\hline 7 & 4-MePh & $\mathrm{Ph}$ & 16 & 73 & 0.3 & 90 & 98 & $R$ \\
\hline 8 & 4-MeOPh & $\mathrm{Ph}$ & 33 & 75 & 0.3 & 97 & 96 & $R$ \\
\hline
\end{tabular}

Table 2. Asymmetric Reduction of $\alpha, \beta$-Unsaturated Ketones

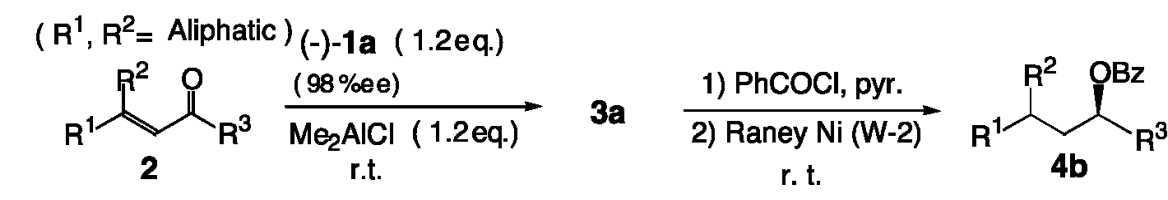

\begin{tabular}{|c|c|c|c|c|c|c|c|c|c|c|c|}
\hline \multirow{3}{*}{ entry } & \multicolumn{5}{|c|}{ Tandem Michael-MPV reaction } & \multicolumn{2}{|c|}{ Benzoylation } & \multicolumn{4}{|c|}{ Reductive desulfuration } \\
\hline & \multicolumn{3}{|c|}{ substrate } & \multirow{2}{*}{$\begin{array}{l}\text { time } \\
\text { (h) }\end{array}$} & \multirow{2}{*}{$\begin{array}{c}\text { yield } \\
3 a(\%)\end{array}$} & \multirow{2}{*}{$\underset{\text { (h) }}{\text { time }}$} & \multirow{2}{*}{$\begin{array}{l}\text { yield } \\
(\%)\end{array}$} & \multirow{2}{*}{$\begin{array}{l}\text { time } \\
\text { (h) }\end{array}$} & \multirow{2}{*}{$\begin{array}{c}\text { yield } \\
4 \mathrm{~b}(\%)\end{array}$} & \multirow[b]{2}{*}{$\%$ ee } & \multirow{2}{*}{ Config. } \\
\hline & $\mathrm{R}^{1}$ & $\mathrm{R}^{2}$ & $R^{3}$ & & & & & & & & \\
\hline 1 & $\mathrm{Me}$ & Me & $\mathrm{Me}$ & 16 & 90 & 2 & 96 & 1.5 & 75 & 98 & $s$ \\
\hline 2 & $\mathrm{H}$ & $\mathrm{H}$ & $\mathrm{Me}$ & 12 & 82 & 12 & 96 & $2^{\mathrm{a})}$ & 73 & 98 & $S$ \\
\hline 3 & $\mathrm{H}$ & $\mathrm{H}$ & Pent & 15 & 82 & 21 & 99 & 31 & 77 & 97 & $R$ \\
\hline 4 & $\mathrm{Me}$ & $\mathrm{H}$ & $\mathbf{P h}$ & 24 & 95 & 16 & $96^{\mathrm{b})}$ & 24 & 86 & 93 & $R$ \\
\hline
\end{tabular}

$\begin{array}{ll}\text { a) reflux at } 90^{\circ} \mathrm{C} & \text { b) methoxymethylation }\end{array}$

5 を収率よく与えたが, 高温で長時間を必要とする 場合は光学純度の低下が観察された（Table 3)。

上記の Tandem Michael-MPV 反応はカブト虫の 防御フェロモン（Chart 6）やプロスタグランジン 誘導体（Chart 7）の不斉合成に適用できることが 示された. ${ }^{1,4)}$

一方, 上記の光学活性 1,3-メルカプトアルコー ル 1 の2-位に水素原子をもつ不斉反応剂を用いた 場合，その生成物の塩基処理により下図（Chart 8) 中に示された機構でメルカプトアルコールが生成す
ると予想された．本変換反応が実現すると反応基質 と不斉反応剂に含まれる 2 つ官能基が互いに交換 され, 不斉合成を伴う 2 官能基交換型変換反応を開 発できることになる.この変換反応では, 不斉反応 剂は光学活性な $\alpha, \beta$-不飽和ケトンになるため, 不 斉反応剂の再生も可能となる.

上記観点より，2-位に水素原子をもつ各種の光学 活性 1,3-メルカプトアルコールを検討した結果, 市販のカンファーから誘導した $\mathbf{1 b}$ は $1 \mathrm{a}$ の反応と 比べて化学収率は低下するものの最も良い結果を与 
Table 3. Synthesis of Allyl Alcohols from Tandem Michael-MPV Products

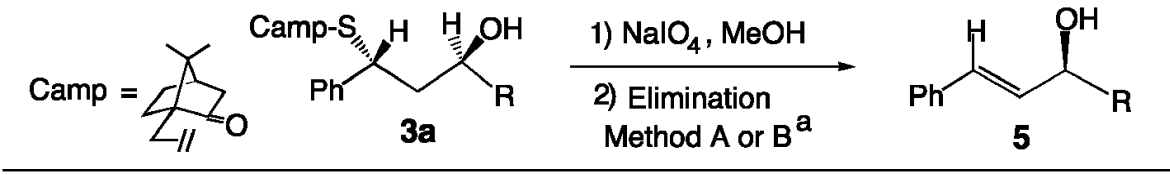

\begin{tabular}{|c|c|c|c|c|c|c|c|c|}
\hline \multirow[b]{2}{*}{ Entry } & \multicolumn{2}{|c|}{ Substrate } & \multirow{2}{*}{$\begin{array}{c}\text { 1) Oxid. } \\
\begin{array}{c}\text { Yield } \\
(\%)\end{array}\end{array}$} & \multicolumn{5}{|c|}{ 2) Elimination } \\
\hline & $\mathrm{R}$ & o.p. $(\%)^{b}$ & & Method & $\begin{array}{c}\text { Time } \\
\text { (h) }\end{array}$ & $\begin{array}{l}\text { Yield }^{c} \\
(\%)\end{array}$ & $\% e^{d}$ & Config. \\
\hline 1 & $\mathrm{Ph}$ & 96 & 95 & $A$ & 4 & 87 & 86 & $R$ \\
\hline 2 & $\mathrm{Ph}$ & 96 & 95 & B & 72 & 72 & 91 & $R$ \\
\hline 3 & $\mathrm{Me}$ & 96 & 98 & $A$ & 4 & 100 & 92 & $S$ \\
\hline 4 & $\mathrm{Bu}$ & 98 & 98 & A & 2 & 93 & 98 & $S$ \\
\hline 5 & Oct & 96 & 100 & A & 4 & 95 & 95 & $s$ \\
\hline
\end{tabular}

a) Method $\mathrm{A}: \mathrm{CaCO}_{3}, 130^{\circ} \mathrm{C}$ in toluene, Method $\mathrm{B}: \mathrm{CaCO}_{3}, 100^{\circ} \mathrm{C}$ in benzene

b) optical purity, c) Isolated yield, d) HPLC analysis.

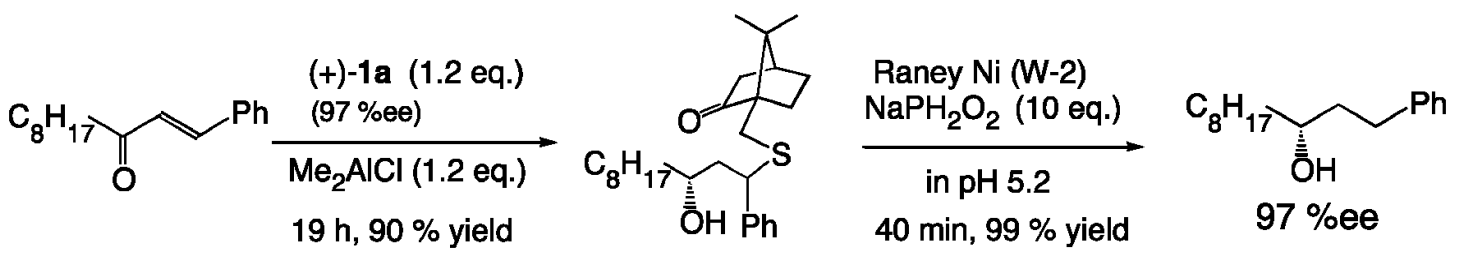<smiles>CCCCCCCC[C@H]1CCC(=O)O1</smiles>

Chart 6

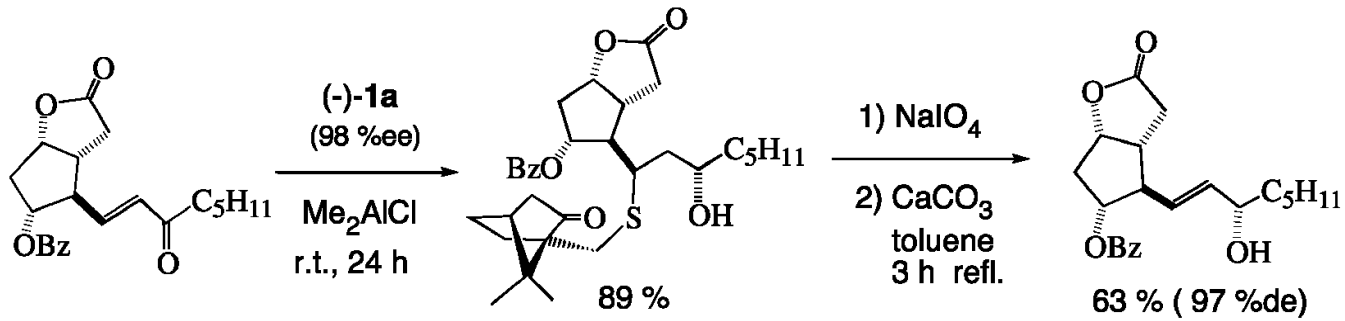

Chart 7

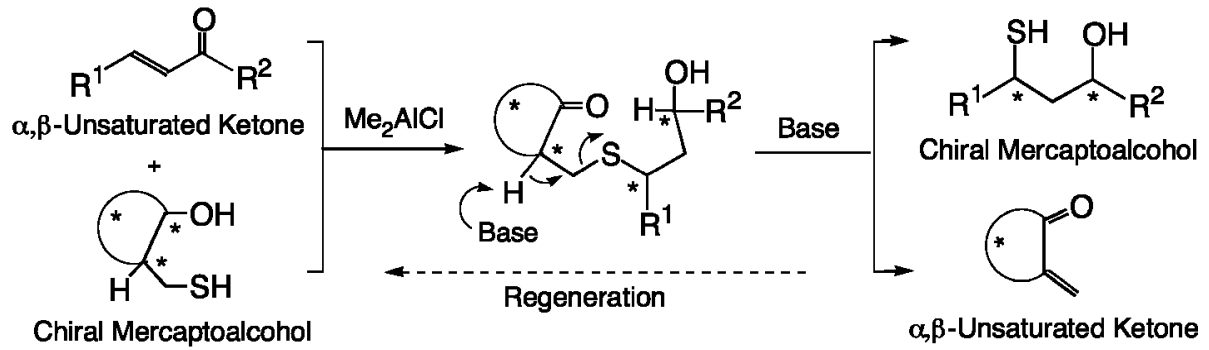

Chart 8. Exchange Reaction of Bifunctional Groups 


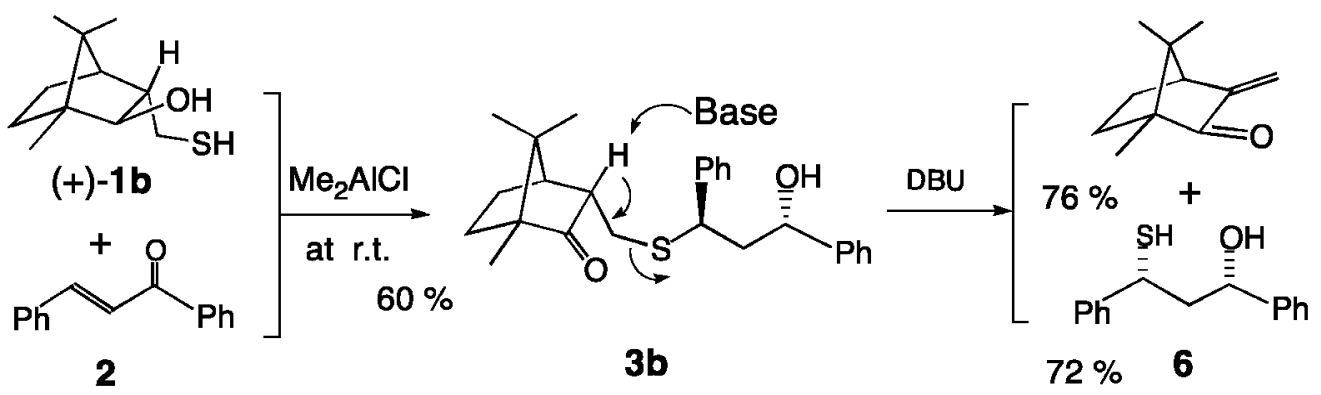

Chart 9

Table 4. Asymmetric Synthesis of 1,3-Mercapto Alcohol

\begin{tabular}{|c|c|c|c|c|c|c|c|c|c|}
\hline \multirow[b]{3}{*}{ Entry } & \multicolumn{3}{|c|}{$\begin{array}{c}(+)-1 \mathrm{~b}(98 \% \\
\stackrel{\begin{array}{c}\text { Menzene } \\
\text { bencl }(1.2 \mathrm{e} \\
\text { r.t. }\end{array}}{\text { benzene }}\end{array}$} & \multirow{3}{*}{ time(h) } & \multirow{3}{*}{$\frac{\text { MPV produc }}{\text { yield (\%) }}$} & \multirow{3}{*}{ 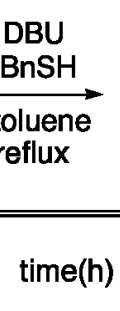 } & \multirow{2}{*}{\multicolumn{3}{|c|}{$\frac{\mathrm{R}_{\mathrm{R}}^{\mathrm{S}}}{\text { mercapto alcohol }}$}} \\
\hline & \multicolumn{3}{|c|}{ Substrate } & & & & & & \\
\hline & $\mathrm{R}^{1}$ & $\mathrm{R}^{2}$ & $\mathrm{R}^{3}$ & & & & yield (\%) & 6-s / 6-a & ee (\%) \\
\hline 1 & $\mathrm{H}$ & $\mathrm{H}$ & $\mathrm{Me}$ & 76 & 50 & 24 & 92 & - & 98 \\
\hline 2 & $\mathrm{Ph}$ & $\mathrm{H}$ & $\mathrm{Me}$ & 21 & 74 & 21 & 96 & $36 / 64$ & 95 \\
\hline 3 & $\mathrm{Ph}$ & $\mathrm{H}$ & $\mathrm{Ph}$ & 48 & 60 & 18 & 97 & $100 / 0$ & 96 \\
\hline 4 & $\mathrm{Ph}$ & $\mathrm{H}$ & Oct & 20 & 50 & 17 & 97 & $47 / 53$ & 98 \\
\hline 5 & $p$-MeOPh & $\mathrm{H}$ & $\mathrm{Ph}$ & 48 & 56 & 18 & 99 & $100 / 0$ & 94 \\
\hline 6 & $p$-Tolyl & $\mathrm{H}$ & $\mathrm{Ph}$ & 44 & 63 & 18 & 92 & $100 / 0$ & 96 \\
\hline 7 & Me & $\mathrm{Me}$ & $\mathrm{Me}$ & 21 & 94 & 14 & 94 & - & 82 \\
\hline 8 & $p$-CIPh & $\mathrm{H}$ & $\mathrm{Ph}$ & 43 & 56 & 22 & 93 & $100 / 0$ & 93 \\
\hline
\end{tabular}

えた。 そこで，不斉反応剤 $\mathbf{1 b}$ の反応で得られる生 成物 3b を塩基処理すると光学活性 1,3-メルカプト アルコール 6 が得られた (Chart 9). 5) 本反応は形 式的に $\alpha, \beta$-不飽和ケトンへ硫化水素の不斉 Michael 付加反応が含まれている点で前例のない反応様式で あり，光学活性チオールの合成法として特に有用で ある。

上記 Tandem Michael-MPV 反応（Table 4）にお いては， $\alpha, \beta$-不飽和ケトンの $\mathrm{R}^{2}$ 基が芳香族であれ ば，単一のジアステレオマーが生成した。しかし， $\mathrm{R}^{2}$ 基が脂肪族である場合は，硫黄原子をもつ炭素 上でジアステレオマーの混合物となることが観察さ れた。本反応では Chart 10 の Michael 付加体 $\mathbf{C}$ 及 び $\mathbf{D}$ において， $\mathrm{R}^{2}$ 基が脂肪族の場合は両者とも $\mathrm{MPV}$ 反応が進行するのに対し， $\mathrm{R}^{2}$ 基が芳香族の場
合は D における立体障害により $\mathbf{C}$ のみが反応して 動的速度論分割が起こると考えられる。また， $3 \mathbf{b}$ から塩基の作用による脱離反応は平衡反応である.

この平衡を生成物側に完全に偏らせるには，ベンジ ルメルカプタンなどのチオールを添加すると収率よ くメルカプトアルコール 6 を得ることができた.

上記反応を $\alpha$ 位に置換基をもつ $\alpha, \beta$-不飽和エス テルに適用したところ，(+)-1a の Michael 付加反 応は不斉プロトン化を伴って進行し，その付加体 7 は酸による転位反応（Wagner-Meerwein 転位）と チオール交換反応により $\beta$-メルカプトエステル $\mathbf{8}$ を収率よく与えた (Chart 11). ${ }^{6)}$ なお，本チオール 交換反応には無臭のドデカンチオールを新規に開発 し，悪臭を出さない反応にすることができた.

上記反応は形式的に不飽和エステルへの $\mathrm{H}_{2} \mathrm{~S}$ の 


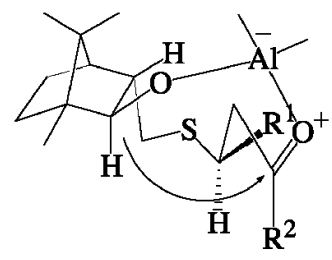

C

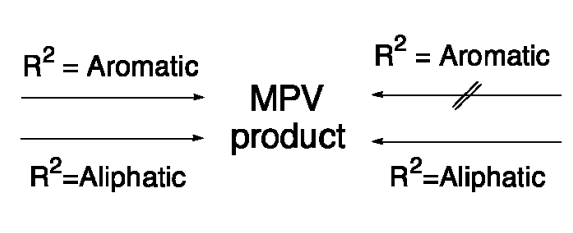

Chart 10. Plausible Structures for MPV Reduction

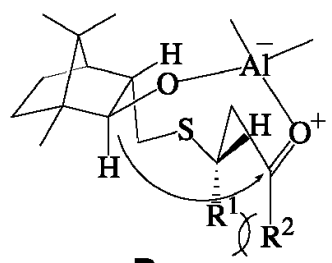

D

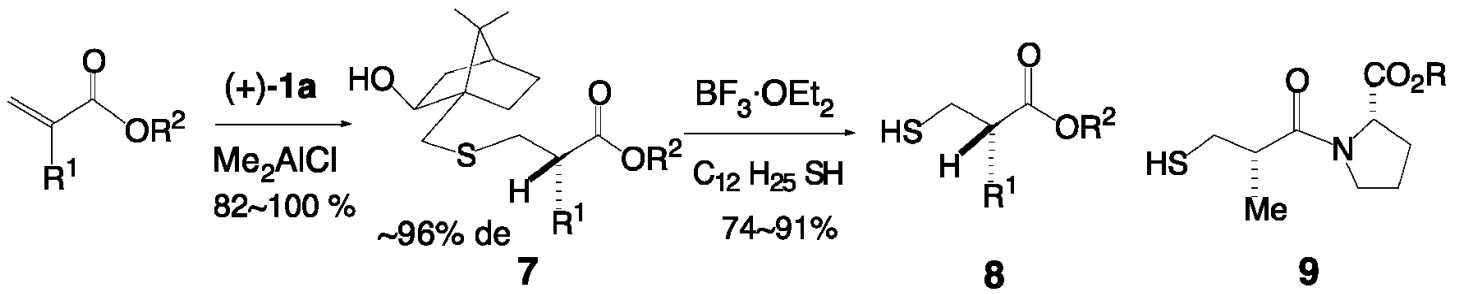

Chart 11

Table 5. Synthesis of Allene-1,3-dicarboxylate Derivatives Using DMC

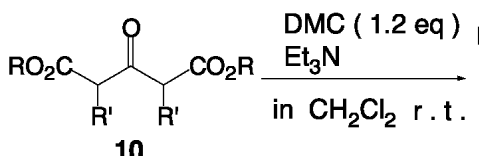

\begin{tabular}{|c|c|c|c|c|c|c|c|}
\hline \multirow{2}{*}{ Entry } & \multicolumn{3}{|c|}{ Substrates } & \multirow{2}{*}{$\mathrm{Et}_{3} \mathrm{~N}(\mathrm{eq})$} & \multirow{2}{*}{ Time $(h)$} & \multicolumn{2}{|c|}{ Products (\% yield) } \\
\hline & & $\mathrm{R}$ & $\overline{\mathbf{R}^{\prime}}$ & & & 11 & 12 \\
\hline 1 & $10 a$ & $\mathrm{Me}$ & $\mathrm{H}$ & 1 & 24 & - & 44 \\
\hline 2 & $10 a$ & $\mathrm{Me}$ & $\mathrm{H}$ & 2 & 22 & 72 & 21 \\
\hline 3 & $10 a$ & $\mathrm{Me}$ & $\mathrm{H}$ & 3 & 1 & 90 & - \\
\hline 4 & $10 b$ & $\mathrm{Me}$ & $\mathrm{Me}$ & 3 & 2 & 73 & - \\
\hline 5 & $10 c$ & Et & $\mathrm{H}$ & 3 & 0.5 & 92 & - \\
\hline 6 & $10 d$ & $\mathrm{Bn}$ & $\mathrm{H}$ & 3 & 2.5 & 70 & - \\
\hline 7 & $10 e$ & ${ }^{t} \mathrm{Bu}$ & $\mathrm{H}$ & 3 & 0.5 & 71 & - \\
\hline
\end{tabular}

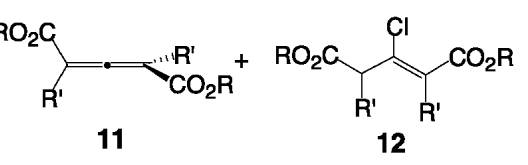

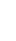

不斉 Michael 付加反応であり, チオール類の合成を 猛毒の硫化水素を用いないで反応が行える点に工業 的有用性がある。本反応はアンジオテンシン変換酵 素阻害薬カプトプリル誘導体 9 の合成に適用できた.

2-2. 付加一脱離型平衡条件下での不斉晶出法 結晶化を用いた不斉変換反応は企業でよく検討され ている手法である，従来法は活性メチンの不斉中心 を塩基でラセミ化させながら光学分割剂との塩又は エステルの一方を優先的に結晶とする手法である. 本法は反応混合物から目的物の分離精製と同時に光 


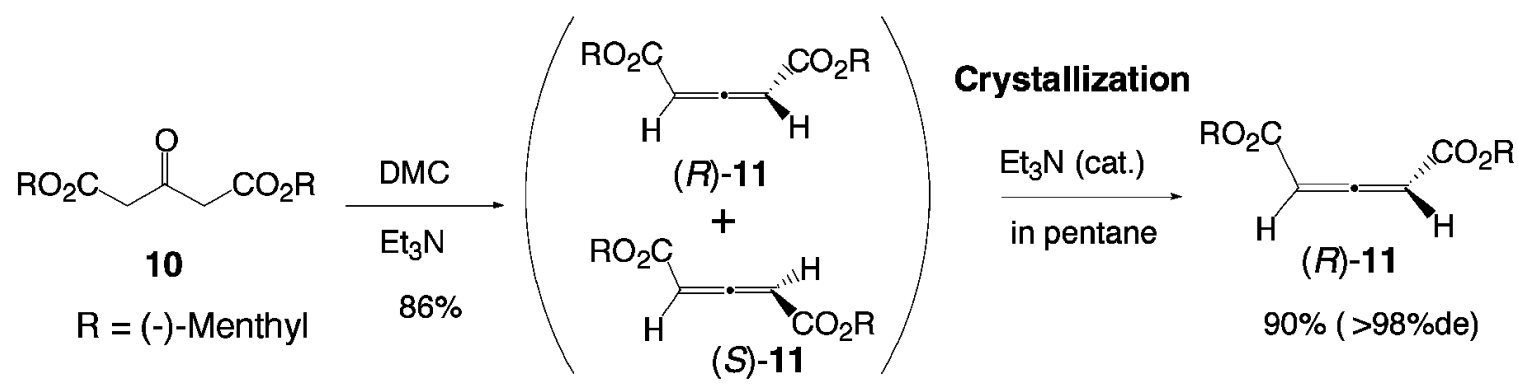

Chart 12. Crystallization - induced Asymmetric Transformation

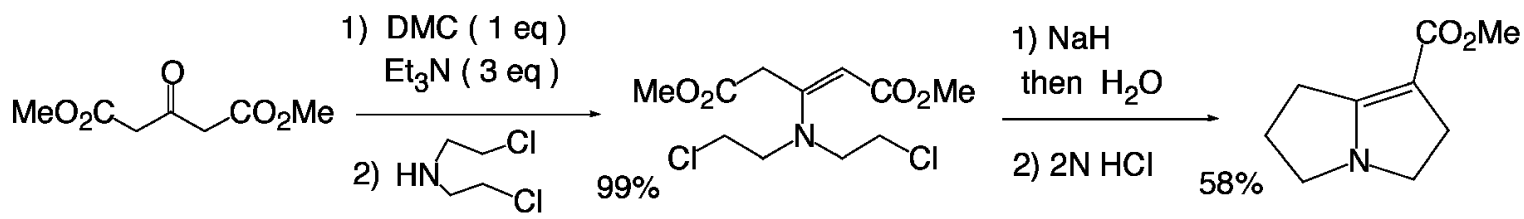

Tandem Cyclization

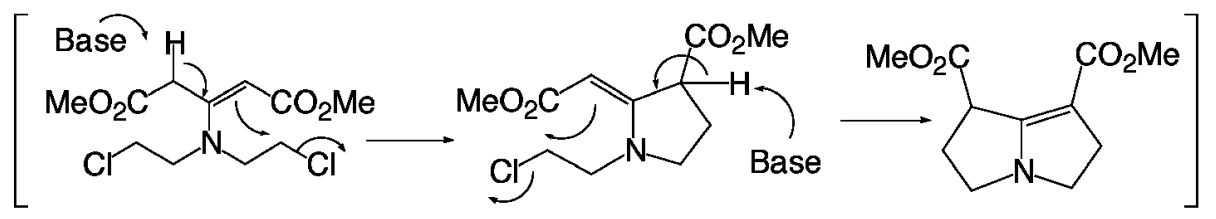

Decarbonylation

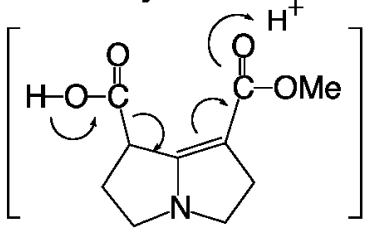

Pyrrolizidine Alkaloids

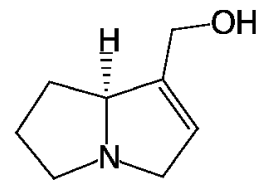

$( \pm)$-Supinidine

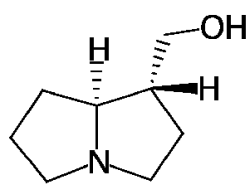

$( \pm)$-Laburnine

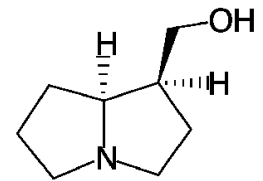

( \pm )-Isoret ronecanol

Chart 13

本反応で使用するトリエチルアミンは，2 当量以 下では副生成物が形成するため, 3 当量以上が必要 である. また, 反応後の処理は抽出操作中に目的物 が分解することが観察され, 反応液を直接シリカゲ ルカラムに充填して分離する方法を用いた.

アレン化合物の不斉合成については，11 のエス テル部に光学活性アルコールを導入したジアステレ オマーの混合物に触媒量の 3 級アミンを添加後, 結 晶化させる新手法 ${ }^{8)}$ を考案した. 本手法により, 高 光学純度のアレン化合物 $\mathbf{1 1}$ を高収率で得ることが できた。本不斉晶出法は前例のない付加・脱離型の 平衡反応を用いており, 活性メチンのエノール化に 限られていた従来の不斉晶出法を拡張できたことに なる (Chart 12).

上述の DMC によるアレン化合物の合成法は bis (2-chloroethyl) amine を用いたエナミン合成に適用 したところ, 収率よく Michael 付加反応が進行し, 得られたエナミンは下図に示す連続環化反応, ジエ ステルの部分加水分解, 及び, 脱炭酸反応によりピ ロリチジンアルカロド類の合成中間体に短工程で導 くことができた (Chart 13).7)

また, 不斉晶出により得られた光学活性アレン化 合物 11 はピロール類との Diels-Alder 反応を鍵反応 とする強力鎮痛活性物質エピバチジンの形式的不斉 全合成に利用できた (Chart 14)。 ${ }^{8}$

2-3. 不斉ニトロオレフィン化反応の改良法 不斉ニトロオレフィン化反応は冨士らにより開発さ れ，キラルニトロエナミン $\mathbf{1 3}$ を不斉反応剂として ラクトン類にニトロオレフィンを導入する不斉 4 級 炭素構築法である. ${ }^{9)}$ 本不斉反応は 6 員環ラクトン 


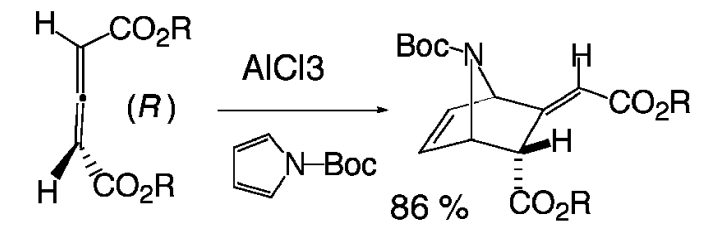

$\mathrm{R}=(-)-$ menthyl
1) $\mathrm{Pd}-\mathrm{C}, \mathrm{H}_{2}$

2) $\mathrm{O}_{3}, \mathrm{PPh}_{3}$

3) $10 \% \mathrm{HCl}$

4) $\mathrm{Boc}_{2} \mathrm{O} / \mathrm{Et}_{3} \mathrm{~N}$

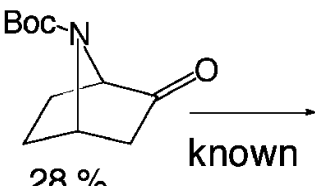

$28 \%$

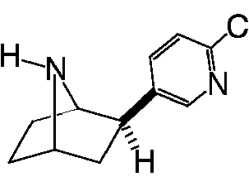

(-)-Epibatidine

Chart 14<smiles>COC[C@H]1CCCN1/C=C(\P)[N+](=O)[O-]</smiles>

13

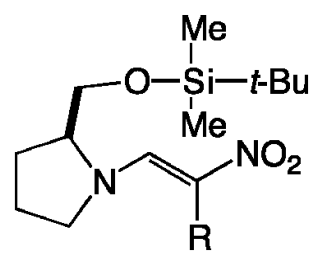

14
Chart 15

Table 6. Asymmetric Nitroolefination of $\delta$-Lactone
には高い不斉収率を与えたが， 5 員環ラクトンやラ クタム類には不斉収率が低くなる欠点が知られてい た，そこで，本研究では上記欠点を克服できる不斉 反応剂 14 を開発することにした（Chart 15）.

そこで，従来の不斉反応剂 13 の不斉補助基であ るプロリノールの水酸基を各種保護基を用いて変換 することを試みた。この結果，嵩高いシリル基で保 護した 14 の反応において不斉収率が改善されるこ とが確認された (Table 6). ${ }^{14,15)}$ 特に， 5 員環ラク トンの不斉ニトロオレフィン化反応では, 従来の 13 では 56\%ee であるのに対して 14 では 88\%ee に まで向上することが確認された（Table 7).

新規不斉反応剂 14 を用いて不斉ニトロオレフィ

Table 7. Asymmetric Nitroolefination of $\gamma$-Lactone
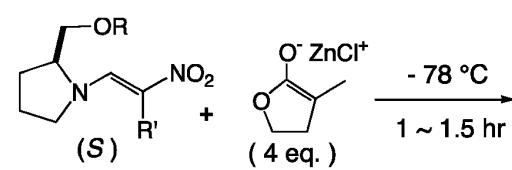<smiles>O=[N+]([O-])/C=C/C12COC1C[Hg]C2</smiles>

\begin{tabular}{lcccl}
\hline \hline $\mathrm{R}^{\prime}$ & $\mathrm{R}$ & Sol. & Yield (\%) & ee (\%) \\
\hline Me & $\mathrm{H}$ & DME & 82 & 56 \\
TBDMS & $\mathrm{H}$ & DME & 92 & 88 \\
TBDMS & $\mathrm{Me}$ & THF & 87 & 93 \\
\hline \multicolumn{2}{l}{ TBDMS $=$ SiMe $_{2}^{\mathrm{t}} \mathrm{Bu}$}
\end{tabular}

ン化反応を一般化し, 生成物 $\mathbf{1 5}$ の光学純度を改善 することができた（Chart 16）. 14,15) 本生成物のニト ロオレフィン部は Michael 付加反応, Diels-Alder 反応， Nef 反応，アミノ基への還元反応等の反応性 に優れ，不斉 4 級炭素をもつ化合物の不斉合成に有 用と考えられる。

そこで，還元的 Nef 反応を用いてニトロオレフ イン 15a をケトンに変換した後, セスキテルテルペ ンである capnellene 類の合成中間体を不斉合成する ことができた（Chart 17）.

一方， ニトロオレフィン 15a と Danishefsky ジエ ンとの Diels-Alder 反応は収率よく進行したが，異 常なエキソ選択性が観察された（Chart 18）.19)こ の異常な選択性はニトロオレフィンの置換基構造に 関係ないことが確認され（Table 8)，Diels-Alder 反 応における遷移状態でニトロ基の酸素アニオンとシ リルエーテルの酸素原子との静電的反発が立体的反 発や Alder の 2 次軌道相互作用より優先すると推論 された.

上記反応で得られた Diels-Alder 付加体 $\mathbf{1 6}$ は酸性 条件で芳香化し，酸化反応により 17 が容易に得ら れることを見いだし，アルカロイドの aphanorphine（Chart 19）や合成鎮痛薬である eptazocine 


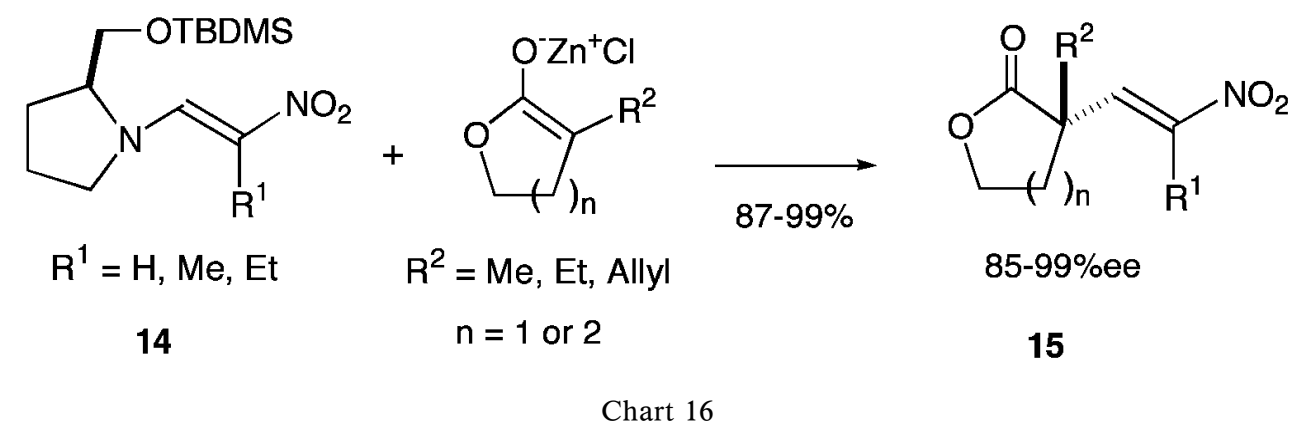

Chart 16<smiles>C/C(=C\C1(C)CCCOC1=O)[N+](=O)[O-]</smiles>

(R )-15a (99\%ee)

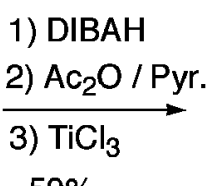
$59 \%$<smiles>CC(=O)CC1(C)CCCOC1OC(C)=O</smiles>
2) $\mathrm{H}_{2} / \mathrm{Pd}-\mathrm{C}$ $88 \%$

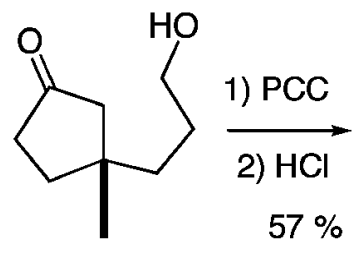<smiles>CC12CCC(=O)[C@H]1[C@H](O)CC2</smiles>

$[\alpha] \mathrm{D}=-160$

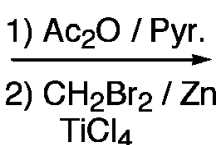
$\mathrm{TiCl}_{4}$ 0<smiles>CC12CCC(=O)C1[C@H](O)CC2</smiles>

1) $\mathrm{KOH}$

$$
[\alpha]_{D}=-100
$$

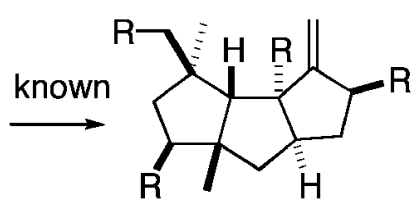

( - ) - $\Delta^{9(12)}$-Capnellenes

Chart 17<smiles>CC1(C=C[N+](=O)[O-])CCCOC1=O</smiles>

$15 a$<smiles>C=C(/C=C/OC)O[Na]</smiles>

O

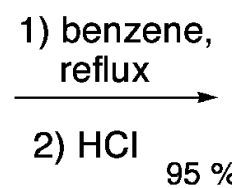

$95 \%$

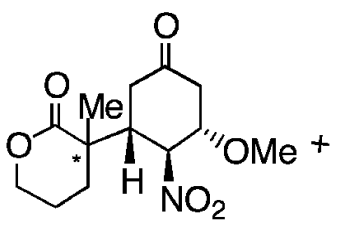

16-exo<smiles>CO[C@H]1CC(=O)C[C@H]([C@H]2CCCOC2=O)[C@H]1[N+](=O)[O-]</smiles>

16-endo

Chart 18

（Chart 20）の合成中間体の不斉合成に応用するこ とができた. ${ }^{17)}$

5 員環ラクトンの不斉ニトロオレフィン化反応で 得られるニトロオレフィン $15 \mathrm{~b}$ は 1 級のニトロ化 合物に還元後, 濃塩酸中で還流するとカルボン酸に 変換され，抗てんかん薬のエトスクシミドの不斉合 成に適用できた (Chart 21). ${ }^{22,24)}$

上記の他，キラルスルフォキシドを含む環式ニト ロオレフィンなどの改良型不斉反応剤11,16) を開発し てきた。また，それらの生成物であるニトロオレフ インは, Michael 付加反応, 10,13,20,21) Diels-Alder 反 応, ${ }^{12,18)}$ アミノ基への還元反応 ${ }^{16,23)}$ などを鍵反応と
して, 不斉 4 級炭素をもつ医薬品類や天然物の不斉 全合成に利用することができた.

\section{3. 生体触媒の不斉反応における新手法の開発}

3-1. 不斉脱アルコキシカルボニル化反応＼cjkstart酵 素によるエステルの加水分解反応やエステル化反応 を不斉反応に利用するには反応基質に対称性化合物 を選ぶ必要がある。本研究では $\beta$-ケト酸の特殊な 反応性（脱炭酸）に着目し， $\sigma$-対称をもつ $\beta$-ケト ジエステルを反応基質として選び，生体触媒を用い て不斉脱アルコキシカルボニル化反応を開発するこ とを目指した。すなわち，本不斉反応においては， 特に合成が容易である $\beta$-ケトジエステル $(\mathbf{1 8}, \mathbf{1 9})$ 
Table 8. Diels-Alder Reaction of Nitroolefins with Danishefsky's Diene

\begin{tabular}{|c|c|c|c|c|}
\hline & $\mathrm{O}_{\mathrm{TMSO}}^{\mathrm{MeO}} 1$ & $\begin{array}{l}\text { 1) benzene } \\
\text { reflux } \\
\text { 2) } 1 \mathrm{~N}-\mathrm{HCl}\end{array}$ & $\begin{array}{l}\mathrm{NO}_{2} \\
\text { exo }\end{array}$ & $\begin{array}{r}\mathrm{NO}_{2} \\
\text { endo }\end{array}$ \\
\hline Entry & $\mathbf{R}$ & Time (d) & Yield (\%) & exo : endo \\
\hline 1 & $o^{\circ} y^{\mathrm{M}}$ & 4 & 74 & $70: 30$ \\
\hline 2 & chexyl & 2 & 42 & $75: 25$ \\
\hline 3 & $t-\mathrm{Bu}$ & 2 & 34 & $71: 29$ \\
\hline 4 & $n$-hexyl & 2 & 36 & $79: 21$ \\
\hline 5 & $\mathrm{Ph}$ & 2 & 60 & $87: 13$ \\
\hline 6 & 3-methoxypheny & 2 & 83 & $91: 9$ \\
\hline
\end{tabular}

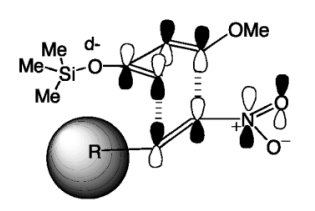

の一方のエステルを酵素を用いて加水分解した後, 得られる $\beta$-ケト酸を酸触媒下で脱炭酸して光学活 性な $\beta$-ケトエステルに変換する手法を計画した (Chart 22).

反応基質である $\sigma$-対称テトラエステル 18 は市販 のアセトン-1,3-ジカルボン酸ジメチルエステル 10 を原料とした Weiss 反応により 1 工程で合成できる が，生成物の構造は溶液中ではケト型ではなく， $C_{2}$ 一対称性をもつエノール型であつた。しかし，ケ トーエノールの互変異性は平衡反応であるため，酵 素によるエステルの光学的な識別は可能であると考 えた.さらに，ビシクロ [3.3.0] オクタン環の左 右の環における化学的環境は同じであるため，4 個 のエステルの内，左右のエステル基が加水分解され て $C_{2}$-対称のジカルボン酸が生成すると考えられた (Chart 23).

そこで，各種リパーゼを用いてテトラメチルエス テル 18 の不斉加水分解反応を試みたところ，反応

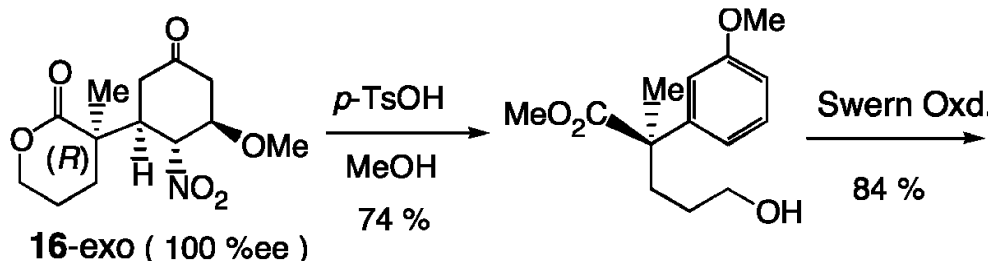<smiles>COC(=O)[C@](C)(CCC=O)c1cccc(OC)c1</smiles>

16-exo ( $100 \%$ ee )$$
74 \%
$$<smiles>COc1ccc2c(c1)[C@@](C)(C(C)OC)CC=C2</smiles>

Chart 19

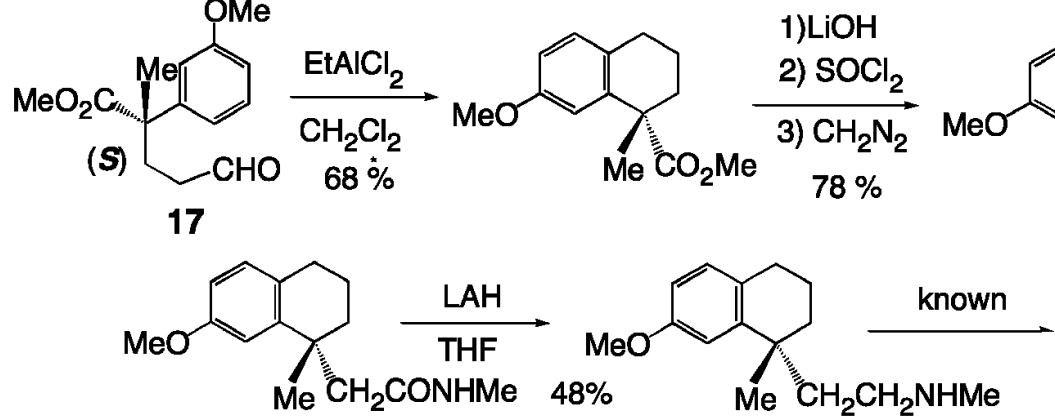

(B)<smiles>CN1C[C@]2(C)C[C@H]1Cc1ccc(O)cc12</smiles>

(-)-aphanorphine

Chart 20 
<smiles>CC1(/C=C/[N+](=O)[O-])CCOC1=O</smiles>

(S)-15b

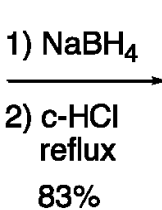<smiles>CC1(CC(=O)O)CCOC1=O</smiles>

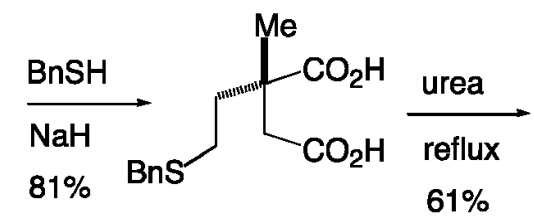<smiles>CCC1(CCSCc2ccccc2)CC(=O)NC1(C)CC(C)(C)C</smiles>

(+)-ethosuximide<smiles>CCCC(C)C(=O)C(C)C(=O)O</smiles>

$\beta$-Ketodiester ( o-Symmetry)

\section{Enzyme}

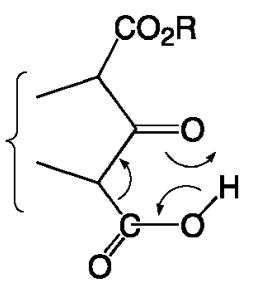<smiles>C[I+]</smiles><smiles>CCC(=O)C(C)C(=O)O</smiles>

$\beta$-Ketoester (Optically Active)<smiles>COCC1C(=O)C(COC)C2(C)C(C(C)=O)C(=O)C(C(=O)OC)C12</smiles>

18<smiles>[R]N1C2CCC1C1C(C(=O)O)C(=O)C2C1OC#P</smiles>

19

Chart 22

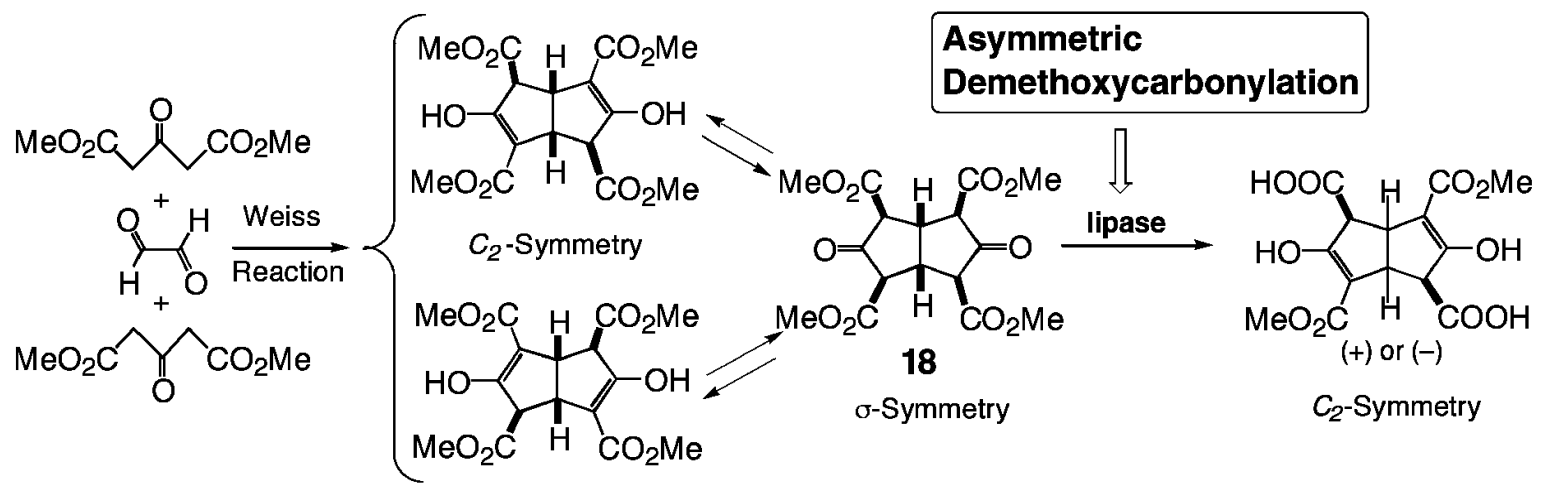

Chart 23

時間は長時間を要するが生成物は加水分解されたカ ルボン酸ではなく，脱炭酸が進行したトリエステル 20 やジエステル 21 であった。生成物の化学収率は 低収率であったが，極めて変化に富んだ結果が得ら
れた（Table 9).25) すなわち, リパーゼの種類によ りトリエステルを生成するものやジエステルを生成 するものがあること，（+）-体を生成する酵素や (一)-体を生成する酵素もあり, さらに, ラセミ体 
Table 9. Asymmetric Demethoxycarbonylation of $\sigma$-Symmetric $\beta$-Ketodiester
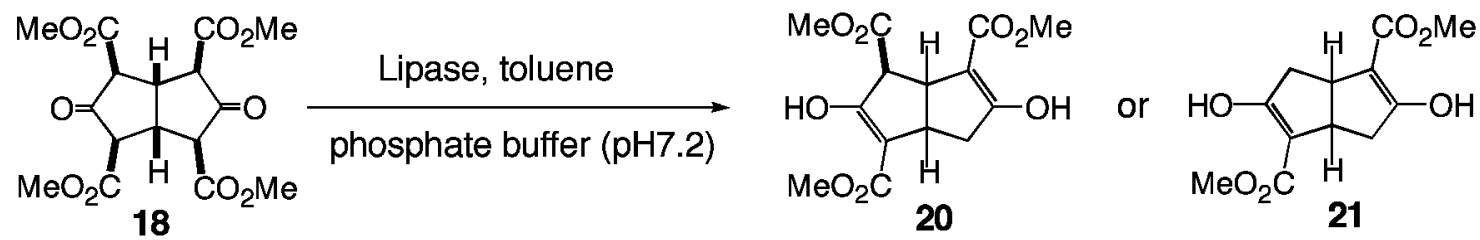

\begin{tabular}{lcc}
\hline \hline \multicolumn{1}{c}{ Lipase } & Yield of 20 & Yield of 21 \\
\hline SIGMA type II (Porcine pancreas) & $43 \%[$ 98.3\% ee(+)] & - \\
Lipase M Amano 10 (Mucor javanicus) & $-20 \%[89.8 \%$ ee $(+)]$ \\
Lipase AY Amano 30 (Candida rugosa) & $35 \%[84.2 \%$ ee(-)] $+32 \%[100 \%$ ee $(-)]$ \\
Lipase F-AP 15 (Rhizopus sp.) & $31 \%[0 \%$ ee $( \pm)]$ & - \\
\hline
\end{tabular}

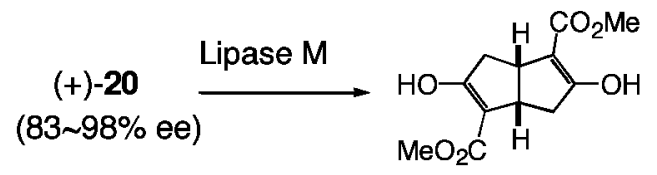

$(+)-21(100 \%$ ee $)$

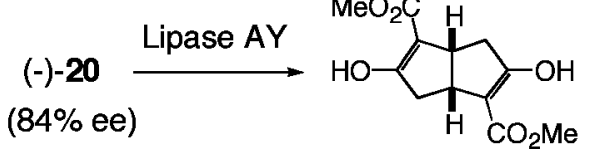

$(-)-21(100 \%$ ee $)$

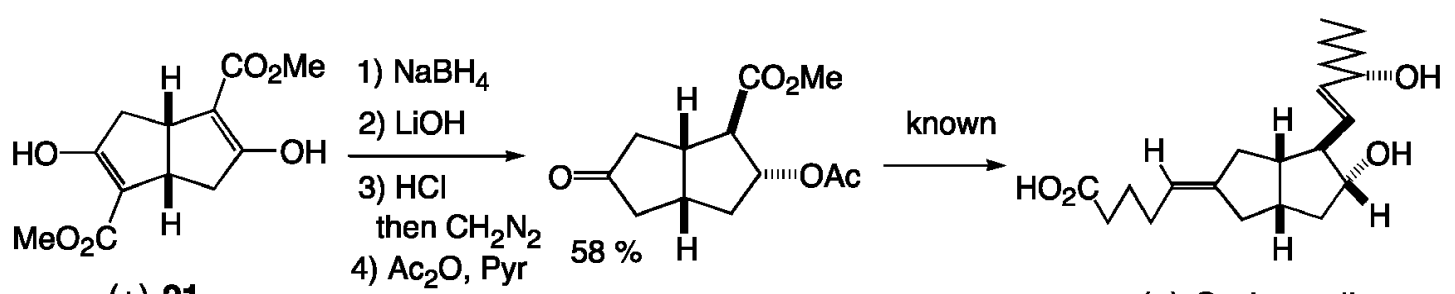

$(+)-21$

4) $\mathrm{Ac}_{2} \mathrm{O}, \mathrm{Pyr}$

$58 \% \quad H$

(+)-Carbacyclin

Chart 24

を生成する酵素も確認された。 また，(一)-体のジ エステル 21 は光学純度の高いものが得られるが, 光学純度の高い $(+)$-体のジエステル 21 は上記反応 で得ることができなかった。そこで，ブタ膵臓リ パーゼ（PPL）より得たトリエステル 20 をリパー ゼ M を用いてジエステル 21 にするか，LiOH でエ ステル 20 の部分加水分解後, 酸で脱炭酸すること により光学純度の高いものに変換することができた.

上記の不斉反応は，基質が簡便に合成できるこ と, 生成物が 2 環性であるため多環式化合物の不斉 合成素子として有用であること，リパーゼの種類に より両鏡像体の造り分けが可能であること，2 環性 の $C_{2}$-対称化合物の不斉合成は前例がないなど多く の特色を有する。 また，本生成物 21 を不斉合成素 子として利用する際， $C_{2}$-対称化合物であるため左
右どちらの 5 員環の官能基と反応しても同じ生成物 になる特徵がある．すなわち，ジケトンの部分還元 と $\beta$-ケトエステルの特徵を活かしてカルバサイク リン合成中間体の短工程不斉合成に成功した (Chart 24). ${ }^{25)}$

また，本不斉合成素子を用いてプロスタグランジ ン関連物質 ${ }^{26,27)}$ を始め，モノテルペンラクトンであ るイリドイド類やアルカロイド類の不斉全合成 ${ }^{27,28)}$ に利用することができた（Chart 25）.

次に， $\sigma$-対称な 2 環性ケトジエステル 19 に対し て上記のリパーゼは反応不活性かラセミ体を与える のみであったが, ブタ肝蔵エステラーゼ（PLE） を用いることによりトロパン型化合物 $(-)-22$ を得 ることに成功した（Table 10）. ${ }^{29)}$ 本反応では，窒 素原子の保護基の種類が不斉反応の進行に大きく関 
<smiles>COCC1=C(O)[C@@H]2CC(O)=C(C(=O)OC)[C@@H]1C2</smiles>

(-)-21 (100\%ee)

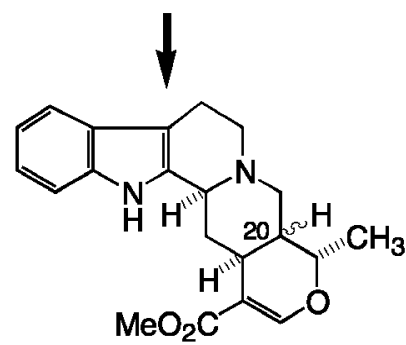

(-)-Tetrahydroalstonine $(20 \alpha-H)$

(-)-Ajmalicine

$(20 \beta-\mathrm{H})$

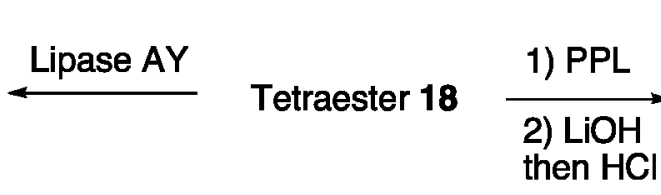<smiles>COC(=O)C1=C(O)CC2C(C(C)=O)=C(O)CC12</smiles>

(+)-21 ( $98 \%$ ee)<smiles>C[C@H]1COC(=O)[C@H]2[C@H]1CC[C@@H](C)[C@H]2C</smiles>

$(-)$-Isoiridomyrmecin $(+)$-lsodihydro- $(+)$-Nepetalactone

$(-)$-Isoiridomyrmecin $(+)$-lsodihydro- $(+)$-Nepetalactone

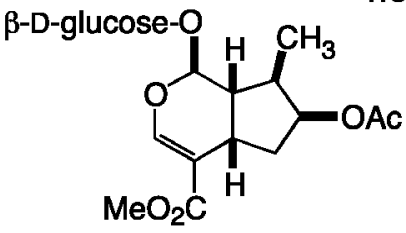

$(-)$-Loganin<smiles>O=C1C[C@H]2[C@@H](CO)C(=O)C[C@H]2O1</smiles>

Corey's lactone

Chart 25

Table 10. Asymmetric Dealkoxycarbonylation

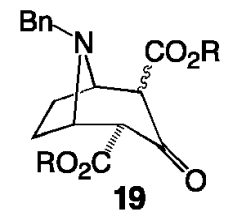

PLE(5000 units / mmol) $0.1 \mathrm{M}$ phosphate buffer $(\mathrm{pH}-8.0)$ r.t., $24 h$

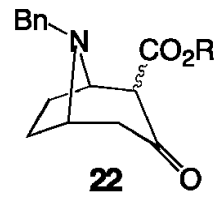

\begin{tabular}{ccccc}
\hline \hline & & \multicolumn{2}{c}{ monoester } & $\begin{array}{c}\text { recovery of } \\
\text { st. mat. (\%) }\end{array}$ \\
\cline { 3 - 4 } entry & $\mathrm{R}$ & yield (\%) & ee (\%) & 21 \\
1 & $\mathrm{Et}$ & 50 & 93 & 30 \\
2 & $i-\mathrm{Pr}$ & 15 & 63 & 31 \\
3 & $\mathrm{Bn}$ & 51 & 74 & 14 \\
4 & $n-\mathrm{Pr}$ & 30 & 93 & 24 \\
5 & $n-\mathrm{Bu}$ & 38 & 95 & 25 \\
6 & $n-\mathrm{Pen}$ & 29 & 94 &
\end{tabular}

与し，カルバメート類やメチル基では成功せず， ベ ンジル基を保護基に用いた時のみ光学活性体が得ら れた。 また，エステル基としては $n$-ブチルエステ ルが最も不斉収率の高い值を示し，メチルエステル では用いる緩衝液（pH 8）により加水分解され， ラセミ化の原因となることが確認された.

本反応においても反応基質 19 の合成が Robinson 法によりアセトン-1,3-ジカルボン酸ジメチルエス
テル 10 から 1 工程で大量合成できる点に特色をも ち, 反応生成物はトロパン型アルカロイド類の全合 成における不斉合成素子として極めて有用であると 思われる。

近年，コカインとドーパミントランスポーターと の親和性が明らかにされ，コカイン誘導体がパーキ ンソン病などの脳内放射性診断薬として開発研究さ れている。しかし，それらの合成には入手困難なコ 
<smiles>O=C(O)C1CC2CCC1N2Cc1ccccc1</smiles>

$(-), 95 \%$ ee.

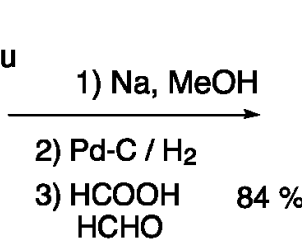

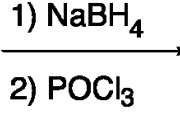

$74 \%$

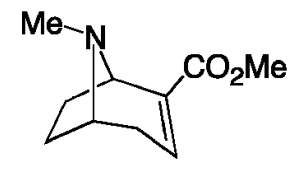

(-)-Anhydroecgonine Methyl Ester

known

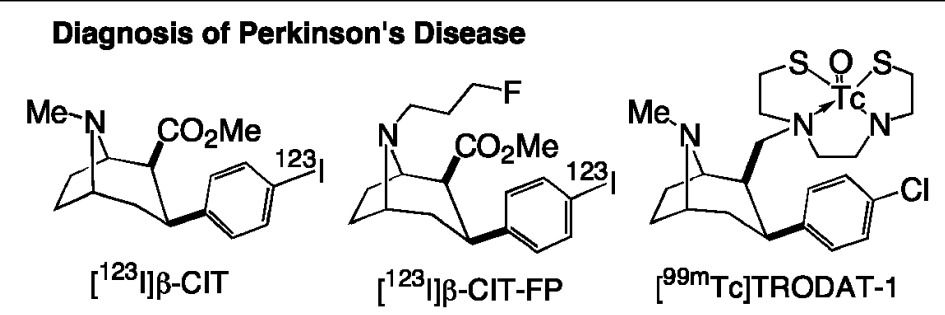

Chart 26

\section{Enantiotopic Protection}<smiles>CCOC(=O)[C@H]1C(=O)CC2CCC([C@H]1O)N2Cc1ccccc1</smiles>

$95 \%$ ee
1) $10 \% \mathrm{Pd}-\mathrm{C} / \mathrm{H}_{2}$

2) $\mathrm{HCHO}, \mathrm{HCOOH}$, $\left(\mathrm{CH}_{2} \mathrm{O}\right)^{n}, \mathrm{MeOH}$

$88 \%$

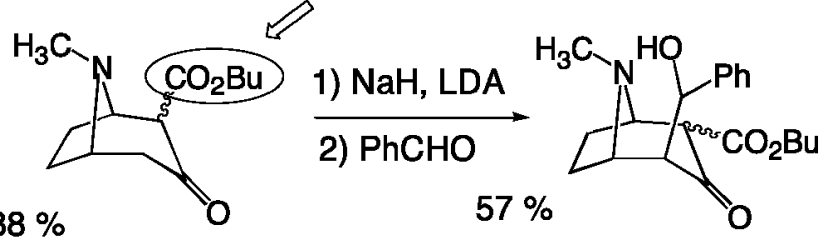

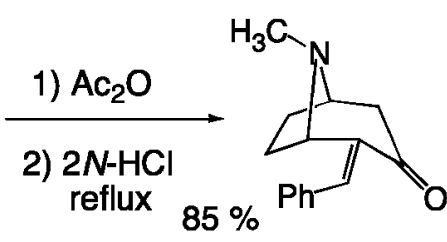

1) $\mathrm{PtO}_{2} / \mathrm{H}_{2}$

2) $\mathrm{Ac}_{2} \mathrm{O}$ $83 \%$<smiles>CC(=O)OC(CO)CC1CCC2CCC1N2Cc1ccccc1</smiles>

Alkaloid KD-B

Chart 27

カインが原料として使われていることから，現在企 業で開発中の $\beta$-CIT, $\beta$-CIT-FP, TRODAT- 1 など の不斉合成に上記の $(-)-\mathbf{2 2}$ を原料とする合成法を 開発することができた (Chart 26). ${ }^{29)}$

また，本合成素子 22 では $\beta$-ケトエステル部のエ ステル基を $\alpha$-炭素の保護基として用いることもで き，トロパン型アルカロイド類の骨格が不斉合成素 子と鏡像体になる化合物の合成にも利用できる，未 報告実験ではあるが，Chart 27 にその合成例を示 した.

3-2. 不斉還元反応と不斉アルドール反応 2 環性化合物の不斉合成素子は前述の $C_{2}$-対称化合 物とともに多環式テルペン類の不斉合成に特に有用 であると考えられた，そこで，市販のシクロペンテ ン類より 3 工程で合成できる 2 環性 $\sigma$-対称ジケト
ン 23 のパン酵母による不斉還元反応を検討した. 本不斉還元反応は長時間を必要とし，比較的低収率 であったが，生成物 $\mathbf{2 4}$ の光学純度は極めて高純度 のものが得られた (Chart 28). ${ }^{30}$ 本合成素子 $(+)$ 24a 及び $(+)-\mathbf{2 4 b}$ を用いることにより，テルペン 類や多環式セスキテルペン類の不斉合成を効率的に 達成できた，特に， capnellene 類の合成中間体の合 成では，前述のニトロオレフィンからの合成経路に 比べ, 半分以下の工程数で合成できた.

不斉アルドール反応については, Candida humicola（AKU4586）から分離した L-threonine aldolase を用いてグリシンとブチルアルデヒド誘導体と の反応を検討したところ，短時間で収率よくアル ドール反応が進行した。本生成物を用いて免疫抑制 物質 mycestericin 類の不斉全合成に成功した 
<smiles>O=C1CCC2CCC(=O)C12</smiles>

23a

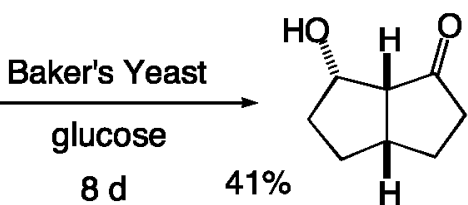

(+)-24a $100 \%$ ee
1) $\left(\mathrm{CH}_{2} \mathrm{OH}\right)_{2} / \mathrm{H}^{+}$

2) $\mathrm{PCC}$

3) $\mathrm{Zn} / \mathrm{CH}_{2} \mathrm{Br}_{2} / \mathrm{TiCl}_{4}$

4) PPTS

$49 \%$<smiles>C=C1CCC2CC[C@@H](O)[C@H]12</smiles>

1) $\mathrm{LDA} / \mathrm{PhSeCl}$

2) $m-C P B A$

3) $\mathrm{CuBr} / \mathrm{Me}_{2} \mathrm{~S}$

$\mathrm{MeMgBr} / \mathrm{TMSCl}$

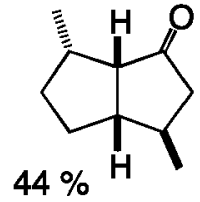

$44 \%$
4) LDATMMCI

5) $\mathrm{O}_{3}$ then $\mathrm{Me}_{2} \mathrm{~S}$

6) $p$-TsOH<smiles>CC1=COC(=O)[C@H]2[C@@H](C)CC[C@H]12</smiles>

cis, cis-Nepetalactone

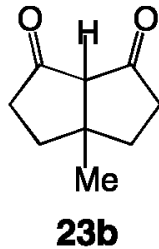

23b

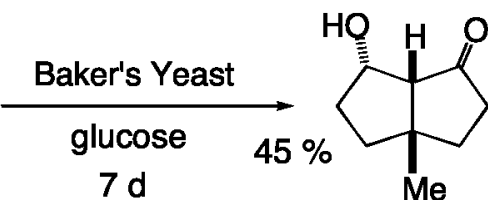

(+)-24b

(99.4\% ee)

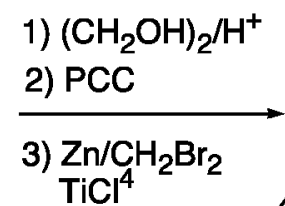

1) $\left(\mathrm{CH}_{2} \mathrm{OH}\right)_{2} / \mathrm{H}^{+}$ $\mathrm{TiCl}^{4}$<smiles>C=C1CCC2([N+](=O)[O-])CCC3(OCCO3)[C@H]12</smiles>

$42 \% \mathrm{Me}$, 1) PPTS 2) $\mathrm{DBU}$

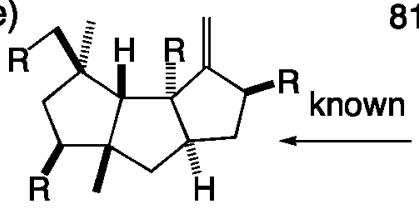

Capnellenes<smiles>CC1=CCC2(C)CCC(=O)C12</smiles>

Cantabrenonic Acid

Chart 28. Asymmetric Reduction of Bicyclo [3.3.0] octane-2,8-dione

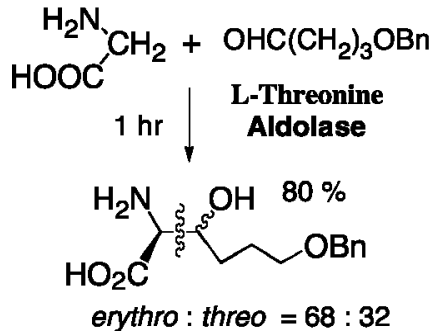

$$
\begin{array}{l|l}
49 \% & \begin{array}{l}
\text { 1) } \mathrm{AC}_{2} \mathrm{O} / \mathrm{Et}_{3} \mathrm{~N} \\
\text { 2) } \mathrm{CH}_{2} \mathrm{~N}_{2} \\
\text { 3) } 1 \mathrm{~N}-\mathrm{HCl} / \mathrm{MeOH} \\
\text { 4) } \mathrm{PhC}(=\mathrm{NH}) \mathrm{OMe}
\end{array}
\end{array}
$$<smiles>COC(=O)[C@H]1N=C([PH2+])O[C@H]1CCCOCc1ccccc1</smiles>

1) $\mathrm{DBU} /\left(\mathrm{CH}_{2} \mathrm{O}\right) \mathrm{n}$ 2) $\mathrm{Ac}_{2} \mathrm{O} / \mathrm{Pyr}$.

3) $\mathrm{AlCl}_{3} / \mathrm{Nal}$ 4) $\mathrm{PCC}$

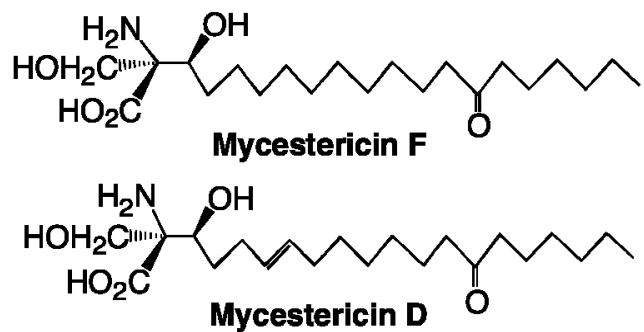

$\uparrow$ 1) Wittig Reaction

$51 \%$

2) $\mathrm{Ac}_{2} \mathrm{O} / \mathrm{Pyr}$.

3) $\mathrm{hv} /(\mathrm{PhS})_{2}$

4) $6 n-\mathrm{HCl}$

5) $2 \mathrm{~N}-\mathrm{NaOH}$<smiles>CCCC1(C)OCCO1</smiles>

Chart 29

(Chart 29). ${ }^{31,32)}$

4. おわりに

以上のように, 新手法による不斉反応の開発を研 究テーマとして上記の成果を得ることができた。し
かし，本当に創薬に役立つものとなると疑問符がつ くものばかりであるが，それを志すところに意義が あると筆者は勝手に考えている，本文中でも少し触 れたが，1,3-メルカプトアルコールを用いる研究で 
気付いたことであるが，それらチオール類の純粋な ものはチオールの悪臭が全く無いことであった．筆 者は長年チオールを使用した研究を行ってきたが, それを大量用いた実験では実験者はもとより大学周 辺にまで悪臭が漂うこともあり，その使用には大き な問題があった。このため, 臭いのしないチオール を市販品や新しく合成した化合物を用いて検索した ところ，数種の無臭チオールを最近開発できた．現 在，それらの有機反応への応用を検討中である.

\section{謝辞本研究は主に京都薬科大学薬品製造学教} 室の教員並びに教室出身者や学生諸君との共同研究 によって達成されたものであり，共同研究者の皆様 に心から謝意を表します。また，折りに触れ御激励 賜りました藤田榮一京都大学名誉教授，並びに，常 に御指導，御鞭撻を賜りました冨士 薰京都大学教 授に厚く御礼申し上げます。

\section{REFERENCES}

1) Nishide K., Shigeta Y., Obata K., Node M., $J$. Am. Chem. Soc., 118, 13103-13104 (1996) .

2) Nishide K., Shigeta Y., Obata K., Inoue T., Node M., Tetrahedron Lett., 37, 2271-2274 (1996) .

3) Node M., Nishide K., Shigeta Y., Obata K., Shiraki H., Kunishige H., Tetrahedron, 53, 12883-12894 (1997)

4) Node M., Nishide K., Shigeta Y., Shiraki H., Obata K., J. Am. Chem. Soc., 122, 1927-1936 (2000).

5) Shiraki H., Nishide K., Node M., Tetrahedron Lett., 41, 3437-3441 (2000).

6) Nishide K., Ohsugi S., Siraki H., Tamakita H., Node M., Org. Lett., in press.

7) Node M., Fujiwara T., Ichihashi S., Nishide K., Tetrahedron Lett., 39, 6331-6334 (1998).

8) Node M., Nishide K., Fujiwara T., Ichihashi S., Chem. Commun., 21, 2363-2364 (1998) .

9) Fuji K., Node M., Nagasawa H., Naniwa Y., Terada S., J. Am. Chem. Soc., 108, 38553856 (1986) ; Fuji K., Node M., Nagasawa H., Naniwa Y.,Taga T.,Machida K., Snatzke G., ibid., 111, 7921-7925 (1989).

10) Node M., Nagasawa H., Fuji K., J. Org. Chem., 55, 517-521 (1990).
11) Fuji K., Node M., Abe H., Itoh A., Masaki Y., Shiro M., Tetrahedron Lett., 31, 24192422 (1990).

12) Node M., Hao X.-J., Fuji K., Chem. Lett., 57 -60 (1991).

13) Hao X.-J., Node M., Fuji K., J. Chem. Soc. Perkin Trans. 1, 1505-1509 (1992).

14) Node M., Kurosaki R., Hosomi K., Inoue T., Nishide K., Ohmori T., Fuji K., Tetrahedron Lett., 36, 99-102 (1995).

15) Nishide K., Kurosaki R., Hosomi K., Imazato H., Inoue T., Node M., Ohmori T., Fuji K., Tetrahedron, 51, 10857-10866 (1995).

16) Fuji K., Kawabata T., Ohmori T., Node M., Synlett, 367-368 (1995).

17) Node M., Imazato H., Kurosaki R., Kawano K., Inoue T., Nishide K., Fuji K., Heterocycles, 42, 811-819 (1996).

18) Node M., Hao X.-J., Nishide K., Fuji K., Chem. Pharm. Bull., 44, 715-719 (1996).

19) Node M., Nishide K., Imazato H., Kurosaki R., Inoue T., Ikariya T., Chem. Commun., 22, 2559-2560 (1996)

20) Hao X.-J., Node M., Fuji F., Chinese Chem. Lett., 8, 949-950 (1997).

21) Hao X.-J., Node M., Fuji K., Chinese Chem. Lett., 8, 951-952 (1997).

22) Nishide K., Katoh T., Imazato H., Node M. Heterocycles, 47, 839-845 (1998).

23) Fuji F., Kawabata T., Omori T., Shang M., Node M., Heterocycles, 47, 951-964 (1998).

24) Katoh T., Nishide K., Node M., Ogura H., Heterocycles, 50, 833-841 (1999).

25) Node M., Inoue T., Araki M., Nakamura D., Nishide K., Tetrahedron Lett., 36, 2255-2256 (1995)

26) Node M., Nakamura D., Nishide K., Inoue T., Heterocycles, 46, 535-540 (1997).

27) Node M., Inoue T., Araki M., Nakamura D., Nishide K., Tetrahedron: Asymmetry, 9, 157167 (1998).

28) Node M., Araki M., Tanaka H., Nakamura D., Inoue T., Nishide K., Chem. Pharm. Bull., 46, 736- 738 (1998).

29) Node M., Nakamura S., Nakamura D., Katoh T., Nishide K., Tetrahedron Lett., 40, 53575360 (1999).

30) Inoue T., Hosomi K., Araki M., Nishide K. Node M., Tetrahedron: Asymmetry, 6, 31-34 
(1995).

31) Shibata K., ShinguK., Vassilev V.P., Nishide K., Fujita F., Node M., Kajimoto T., Wong C. H., Tetrahedron Lett., 37, 2791-2794
(1996).

32) Nishide K., Shibata K., Fujita T., Kajimoto T., Wong C. H., Node M., Heterocycles, 52, 1191-1201 (2000). 